\title{
ANALISIS PERLINDUNGAN HUKUM TERHADAP ANAK SEBAGAI KORBAN PEDOFILIA BERDASARKAN UNDANG-UNDANG NOMOR 11 TAHUN 2012 TENTANG SISTEM PERADILAN PIDANA ANAK
}

\author{
Oleh : Febriyati
}

13144300011

\author{
FAKULTAS KEGURUAN DAN ILMU PENDIDIKAN \\ UNIVERSITAS PGRI YOGYAKARTA 2017
}

\begin{abstract}
ABSTRAK
Tujuan penelitian ini adalah untuk mengetahui dan mengkaji bentuk perlindungan hukum terhadap anak sebagai pedofilia berdasarkan UndangUndang Nomor 11 Tahun 2012 tentang Sistem Peradilan Pidana Anak dan mengetahui upaya pemerintah dalam melindungi korban pedofilia.

Metode dalam penulisan skripsi ini adalah penelitian hukum normatif. Penelitian dilakukan dengan melakukan pendekatan perundang-undangan dan perbandingan. Data yang digunakan merupakan data sekunder, yaitu data yang bersumber dari bahan pustaka. Pemaparan data dilakukan dengan mendiskripsikan literatur yang diperoleh dan dianalisis sesuai dengan kajian yang menjadi fokus pembahasan. Analisis data yang digunakan dalam penelitian ini adalah deskriptif yang bersifat deduktif dan induktif.

Simpulan dari penulisan skripsi ini antara lain (1) Bentuk perlindungan hukum terhadap anak sebagai korban pedofilia yaitu: Berdasarkan undang-undang no 11 tahun 2012 antara lain: a).Jaminan keselamatan,baik fisik,mental maupun sosial pada pasal 58 (1) pada saat memeriksa Anak Korban/atau saksi, hakim dapat memerintahkan agar anak dibawa keluar ruang sidang, (2) pada saat pemeriksaan b) Hak mendapatkan pendampingan, dan c) Hak menjalani peradilan dalam situasi khusus untuk anakperkara. (2) Upaya pemerintah sebagai upaya penanggulangan tindak pidana pedofilia yaitu: a) penyuluhan hukum intansi penegak hukum, b) penyuluhan rohani/ agama, c) Melalui upaya preventif, dan d) Melalui upaya represif.
\end{abstract}

Kata kunci : Anak Korban, Anak Saksi, Pedofilia, Perlindungan Hukum. 


\begin{abstract}
The purpose of thesis research is to know and examine the form of legal protection of children as victims of pedophilia based on the law number 11 of 2012 on the Criminal Justice System of Children and know the government's efforts to protect victims of pedophilia

Method in writing this thesis is normative law research. Research is done by approaching legislation and comparison. The data used is secondary data, ie data that comes from library materials. Data exposure is done by describing the literature obtained and analyzed in accordance with the study that became the focus of discussion. Data analysis used in this research is descriptive which is deductive and inductive.

The conclusions of this thesis writing are: (1) The form of legal protection for children as victims of pedophilia, namely: Based on the law no 11 of 2012, among others: a). Security guarantee, physical, mental and social in Article 58 (1) when examining the Victim's Child / or witness, the judge may order the child to be taken out of the courtroom, (2) at the time of the examination b) The right to receive counseling, and c) The right to conduct the trial in a special situation for the child. (2) Government efforts as an effort to overcome pedophile crime are: a) law enforcement law enforcement agencies, b) spiritual / religious counseling, c) through preventive efforts, and d) Through repressive efforts.
\end{abstract}

Keywords: Children Who Were Victims or Witnesses, Phedophile, Legal Protection.

\title{
PENDAHULUAN
}

\section{Latar Belakang Mas alah}

Anak adalah amanah dan karunia Tuhan Yang Esa yang dalam dirinya melekat harkat dan martabat sebagai manusia seutuhnya. Oleh karena itu, terhadap anak yang berhadapan dengan hukum harus mendapat perlindungan dan pengayoman khusus dengan ditetapkannya Undang-Undang Negara Republik Indonesia 1945 telah diamanatkan kepada bangsa Indonesia yang termuat dalam salah satu tujuan Negara Republik Indonesia adalah untuk melindungi segenap bangsa Indonesia, mencerdaskan kehidupan bangsa serta menjamin setiap anak atas kelangsungan hidupnya, tumbuh dan berkembang serta berhak atas perlindungan dari kekerasan dan diskriminasi (Pasal 28b ayat(2) UUD hasil amandemen) 
Undang-Undang Sistem Peradilan Anak yang mengedepankan diversi sebagai bentuk dari restorative justice dalam menyelesaikan perkara pidana yang berkaitan dengan anak. Oleh karena itu, dengan diberlakukannya Undang-Undang ini diharapkan motivasi pengembalian keadaan ke keadaan semula dapat diterapkan dalam kasus yang berkaitan dengan anak, jadi bukan penerapan sistem balas dendam yang dibutuhkan dalam menyelesaikan perkara dimaksud.

\section{Rumusan Masalah}

Perumusan masalah dalam penulisan skripsi ini adalah:

1. Bagaimana bentuk perlindungan hukum terhadap anak sebagai korban pedofilia?

2. Bagaimana upaya pemerintah dalam melindungi anak sebagai korban pedofilia?

\section{Tujuan Masalah}

Adapun tujuan yang ingin dicapai dalam penelitian ini adalah:

1. Mengetahui dan mengkaji bentuk perlindungan hukum terhadap anak sebagai pedofilia berdasarkan Undang-Undang Nomor 11 Tahun 2012 tentang Sistem Peradilan Pidana Anak.

2. Mengetahui bagaimana upaya pemerintah dalam melindungi korban pedofilia.

\section{Manfaat Penelitian}

Manfaat penulisan skripsi ini dapat dikelompokan menjadi dua yaitu manfaat secara teoritis dan manfaat secara praktis.

1. Manfaat Teoritis

a. Penulisan skripsi ini nantinya dapat menjadi bahan kajian bagi penulisan skripsi lanjutan dan sebagai perbandingan maupun tujuan lain yang relevan.

b. Penulisan skripsi ini nantinya dapat memberikan sumbangan pengetahuan tentang hukum pidana, khususnya kasus anak sebagai 
korban pedofilia di Indonesia berdasarkan Undang-Undang Nomor 11 tahun 2012 tentang Sistem Peradilan Pidana Anak.

2. Manfaat Praktis

a. Menambah referensi para pihak tentang betapa pentingnya pemberian perlindungan anak sebagai wujud pelaksanaan hak-hak anak.

b. Untuk lebih mengembangkan penalaran, membentuk pola pikir dinamis sekaligus untuk mengetahui kemampuan penulis dalam menerapkan ilmu yang diperoleh.

\section{KAJIAN TEORI}

\section{Kebijakan Perlindungan Anak}

Dalam berbagai peraturan perundang-undangan Indonesia, tidak terdapat pengaturan yang tegas tentang kriteria anak. Lain peraturan perundangan-undangan lain pula kriteria anak. Pasal 330 Kitab Undangundang Hukum Perdata menentukan bahwa belum dewasa apabila belum mencapai umur 21 ( dua puluh satu) tahun dan tidak lebih dahulu telah kawin. Anak adalah orang yang berumur dibawah 18 (delapan belas).

Undang-Undang Perlindungan Anak mengatur tentang asas dan tujuan perlindungan anak yakni pasal 2 dan pasal 3, sebagai berikut:

Pasal 2: penyelenggara perlindungan anak berasaskan Pancasila dan berlandaskan Undang-Undang Dasar Negara Republik Indonesia Tahun 1945 serta prinsip-prinsip dasar konvensi hak anak meliputi:

1) Non diskriminasi

2) Kepentingan yang terbaik bagi anak

3) Hak untuk hidup, kelangsungan hidup, dan perkembangan

4) Penghargaan terhadap anak.

\section{Pengertian Tentang Korban}

Pengertian istilah korban tindak pidana sudah dikenal sejak adanya kejahatan. Pada umumnya dapat dikatakan bahwa tidak ada kejahatan tanpa adanya korban, tidak adanya korban tanpa adanya pelaku. Korban suatu kejahatan tidaklah selalu berupa individu, atau orang perorangan, tetapi bisa juga berupa kelompok orang, masyarakat atau juga badan hukum. Bahkan ada 
korban yang berasal dari kehidupan lainnya seperti tumbuhan, hewan ataupun ekosistem.

\section{Tindak Pidana Kekerasan Seksual Pedofilia}

Tindak pidana merupakan pengertian dasar dalam hukum pidana (yuridis normatif) yang berhubungan dengan perbuatan yang melanggar hukum pidana. tindak pidana menurut adalah suatu pelanggaran terhadap norma, yang dilakukan karena kesalahan pelanggar dan diancam dengan pidana untuk mempertahankan tata hukum dan menyelamatkan kesejahteraan umum sedangkan menurut hukum positif adalah suatu kejadian yang oleh peraturan undang-undang dirumuskan sebagai perbuatan yang dapat dihukum.

Pedofilia berasal dari bahasa Yunani, terdiri dari dua suku kata, pedo berarti anak dan phile berarti dorongan yang kuat atau cinta. Pedofilia adalah salah satu kelainan seksual yang termasuk dalam kategori parafilia. Istilah parafilia pertama kali disebutkan oleh seorang psikoterapis bernama Wilhelm Stekel dalam bukunya yang berjudul Sexual Aberation tahun 1925.

\section{METODE PENELITIAN}

Penulisan dalam skripsi ini menggunakan metode penelitian hukum normatif, yaitu penelitian dengan cara mengkaji peraturan perundang-undangan yang berlaku atau diterapkan terhadap suatu permasalahan hukum tertentu (Soerjono Soekanto, 2014: 52)

Data yang digunakan dalam penulisan skripsi ini adalah data sekunder, yaitu data yang bersumber dari bahan pustaka.

Metode pengumpulan data yang digunakan dalam penulisan skripsi ini adalah studi kepustakaan, yaitu serangkaian kegiatan yang berkenaan dengan pengumpulan data pustaka, membaca, dan mencatat serta mengolah bahan penelitian sehingga diperoleh data yang dibutuhkan dalam penelitian (Mestika Zed, 2008: 3). 


\section{TEMUAN DAN PEMBAHASAN}

\section{A. Bentuk perlindungan hukum terhadap anak sebagai korban pedofilia}

Berdasarkan Undang-Undang Nomor 11 Tahun 2012 tentang Sistem Peradilan Anak:

a. Jaminan Keselamatan, baik fisik, mental maupun sosial.

Undang-undang No. 11 Tahun 2012 tentang Sistem Peradilan Pidana Anak mengatur perlindungan mengenai jaminan keselamatan anak yang menjadi saksi dalam kasus pedofilia dalam Pasal 90 Ayat (1) butir (b) yang menyebutkan "jaminan keselamatan, baik fisik, mental, maupun sosial". Jaminan keselamatan diperlukan sebagai seorang anak yang menjadi saksi dalam sidang peradilan pidana.

b. Hak Mendapatkan Pendampingan

Hal lain berkaitan dengan keselamatan yaitu keamanan dan kenyamanan anak yang menjadi saksi diatur pula dalam Undang-undang No. 11 Tahun 2012. Pada Ayat (1) di atas, diketahui bahwa anak yang menjadi saksi dalam perkara pidana dapat dititipkan kepada lembaga perlindungan atau lembaga kesejahteraan sosial anak. Hal ini dapat dilakukan karena hasil pengamatan dari para pendamping anak tersebut melihat bahwa anak saksi yang bersangkutan memang memerlukan suatu perlindungan khusus. Demikian juga pada Ayat (4), penyidik maupun pihak lain dapat meminta lembaga peradilan untuk menyediakan rumah perlindungan saksi maupun perlindungan sosial di suatu tempat khusus. Setiap anak berhak mendapat pelindungan dari tindakan yang merugikan, menimbulkan penderitaan mental, fisik dan sosial.

c. Hak Menjalani Peradilan dalam Situasi Khusus untuk Anak

Menurut Undang-undang No. 11 Tahun 2012 tentang Sistem Peradilan Pidana Anak Pasal (1) Ayat (5) disebutkan bahwa anak saksi adalah seseorang dengan pembatasan usia di bawah 18 tahun yang dapat memberikan keterangan guna kepentingan penyidikan, penuntutan, dan 
pemeriksaan di sidang pengadilan tentang suatu perkara pidana yang didengar, dilihat, dan/atau dialaminya sendiri.

B. Upaya pemerintah dalam pemberian perlindungan hukum terhadap anak sebagai korban pedofilia:

Pemerintah dalam upaya penanggulangan kejahatan seksual, antara lain: Penyuluhan hukum, Penyuluhan rohani/agama, melalui upaya preventif dan represif kemudian memasukkan kurikulum tentang pelajaran seksual, masalah seksual dan kejahatan seksual pada semua level pendidikan sekolah.

1. Penyuluhan hukum instansi penegak hukum yang dilakukan polisi dalam upaya pencegahan dan penanggulangan kejahatan adalah memberikan himbauan dan melakukan patroli rutin untuk meningkatkan suasana aman dan tentram

2. Penyuluhan rohani/agama, melalui penyuluhan keagamaan diharapkan keimanan seseorang terhadap agama kepercayaannya semakin kokoh, serta dimanifestasikan dalam perilaku yang baik sehari-hari di dalam masyarakat.

3. Upaya preventif adalah suatu pengendalian sosial yang dilakukan untuk mecegah kejadian yang belum terjadi dapat dilakukan oleh orang tua, guru sebagai pendidik, masyarakat.

4. Upaya represif adalah pengendalian sosial setelah terjadi penyimpangan kepada anak korban pedofilia melalui bimbingan konseling, pelayanan bantuan medis dan bantuan hukum. 


\section{SIMPULAN DAN SARAN}

\section{A. Simpulan}

1. Bentuk perlindungan hukum terhadap anak sebagai korban pedofilia yaitu: Berdasarkan undang-undang no 11 tahun 2012 antara lain: a) Jaminan keselamatan, baik fisik, mental maupun sosial pada pasal 58 (1) pada saat memeriksa Anak Korban/atau saksi, hakim dapat memerintahkan agar anak dibawa ke luar ruang sidang, (2) pada saat pemeriksaan b) Hak mendapatkan pendampingan, dan c) Hak menjalani peradilan dalam situasi khusus untuk anak.

2. Upaya pemerintah sebagai upaya penanggulangan tindak pidana pedofilia yaitu: a) penyuluhan hukum intansi penegak hukum, b) penyuluhan rohani/ agama, c) Melalui upaya preventif, dan d) Melalui upaya represif.

\section{B. Saran}

Berdasarkan uraian skripsi ini, penulis memberikan saran a) Pemerintah dapat memberikan hukuman yang lebih berat yang dapat menimbulkan efek jera dan pemerintah setelah ini mengatur tentang Kastrasi yang menimbulkan kontroversi sebagai hukuman tambahan harus benar-benar dikaji jika akan dijadikan landasan hukum untuk menghukum pelaku pedofil. b) Komisi Perlindungan Anak Indonesia (KPAI) harus meningkatkan efektifitas penyelenggaraan perlindungan anak dalam masalah kekerasan dilaksanakan secara nyata dan efektif oleh seluruh pemerintah daerah di Indonesia. 


\section{DAFTAR PUSTAKA}

\section{Buku}

Andrisman, Tri. 2009. Hukum Pidana "Asas-Asas dan Dasar Aturan Umum Hukum Pidana”, Universitas Lampung, Bandar Lampung.

Anjar, Anan. 2013. Konsep Diversi Dan Restoratif. (http://anjarnawanyep.worpress.com). Di unduh 20 mei 207

Arif Gosita. 2004. Masalah Korban Kejahatan. Jakarta: PT Buana Ilmu POPULER Kelompok Gramedia.

Asmawi, Mohammad. Lika-Liku Seks Menyimpang Bagaimana Solusinya, (Darussalam Ofset, 2005). Nuansa Cendikia.

Baskara, Leo. 2012. Pedofilia. (www.scribd.com. Diunduh : 25 Mei 2017)

Chazawi, Adami. 2002. Pelajaran Hukum Pidana. Jakarta: PT Raja Grafindo Persada.

Davison, Gerald C. Neale, dkk. 2006. Psikologi Abnormal, Edisi ke-9. Jakarta : Rajawali Pers.

Desminta. 2013.Psikologi Perkembangan. Bndung: PT. Remaja Roadakarya.

Didik M. Arif Mansur, dkk. 2007. Urgensi Perlindungan Korban Kejahatan Antara Norma Dan Realita. Jakarta: PT Raja Grafindo Persada.

Gultom, Maidin. 2008, Perlindungan Hukum Terhadap Anak Dalam Sistem Peradilan Pidana Anak Di Indonesia, Refika Aditama, Bandung

Gultom, Maidin. 2012, Perlindungan Hukum Terhadap Anak dan perempuan, Refika Aditama, Bandung

Halgin.P, Ricahard dan Whitbourne Krauss Susan. 2010. Psikologi Abnormal. Jakarta. Salemba Humanika.

Mansyur, Ridwan, 2014, Keadilan Restoratif Sebagai Tujuan Pelaksanaan Diversi Pada Sistem Peradilan Pidana Anak. (www.mahkamahagung.go.id). Di unduh 20 Mei 2017.

Maulana, Hassan W., 2000, Pengantar Advokasi dan Hukum Perlindungan Anak, Gramedia Widiasarana Indonesia, Jakarta

Moeljatno. 2008, Asas-asas Hukum Pidana, PT. Rineka Cipta, Jakarta. 
Nawawi, Hadari. 2008. Metode Penelitian Bidang Sosial. Yogyakarta: Gadjah Mada University Press.

P.A.F. Lamintang. 1997. Dasar-Dasar Hukum Pidana Indonesia. Bandung: PT Citra Aditya Bakti.

Ronosulistyo Hanny dan Aam Amirudin. 2004. Seks tak Sekedar Birahi, Panduan Lengkap Seputar Kesehatan Reproduksi: Tinjauan Islam dan Medis. Bandung: Gernada

Soekanto, Soerjono, 2014, Pengantar Penelitian Hukum, UI Press, Jakarta.

Soemitro, Setyowati, I. 1990. Aspek Hukum Perlindungan Anak. Bumi Aksara. Jakarta

Sudarto. 2006, Kapita Selekta Hukum Pidana. Alumni, Bandung.

Sukardi. 2004. Metodologi Penelitian Pendidikan. Yogyakarta: Bumi Aksara.

Wahyu, Anggoro Purwadi. 2016. Studi Korban Kekerasan Seksual di Yogyakarta. (www.jurnal.ums.co.id)

Zainuddin, Ali. 2015. Metode Penelitian Hukum. Jakarta: Sinar Grafika.itian Hukum. Jakarta: Sinar Grafika.

Zed, Mestika. 2008. Metode Penelitian Kepustakaan. Jakarta: Yayasan Obor Indonesia.

\section{Peraturan}

Undang-Undang Dasar Negara Republik Indonesia Tahun 1945

Undang-Undang Nomor 11 Tahun 2012 Tentang Sistem Peradilan Anak,

Undang-Undang Nomor 35 Tahun 2014 tentang Perubahan atas Undang-Undang Nomor 23 Tahun 2002 Tentang Perlindungan Anak

Undang-Undang Nomor 4 Tahun 1979 Tentang Kesejahteraan Anak.

Undang-Undang Nomor 13 Tahun 2006 tentang Perlindungan Saksi dan Korban

Peraturan Komisi Perlindungan Anak Indonesi Nomor 2 Tahun 2014 Tentang

Pedoman Pelaksanaan Pemantauan, Evaluasi

\section{Internet}

(www.kpai.go.id. Diakses :15 Mei 2017).

(indonesia -@igc.apc.org. Diakses : 15 Mei)

(http://www.komnaspa.or.id. Diakses: 20 Mei 2017)

(http://www.metronews.co.id. Diakses: 15 oktober 2017) 